\title{
IUGS Task Group on Public Affairs
}

\author{
http://www.agiweb.org/gap/iugs
}

\section{Background}

International collaboration is standard practice among geoscientists, but the public policies that should be informed by geoscience data and understanding remain stubbornly locked within national borders. Because geoscience policy challenges, like geological processes, pay little heed to political boundaries, mechanisms are needed to translate the policy experience of geoscientists in one country to other geoscientists seeking to affect the environmental, resource, natural hazards, and geoscience education policies in their countries.

Although mechanisms exist for concerted action on geoscientific issues among governments-such as the United Nations Educational, Scientific and Cultural Organization-IUGS has recognized the need to develop a mechanism for geoscience organizations to share information on geoscience-related public policy activities, focusing on the common challenges faced by geoscientists in many different countries. For example, geoscience societies in one country may have developed position statements that could be used by societies in another country. Successful geoscience involvement in a policy issue in one nation can provide a recipe for similar action in another.

The IUGS Task Group on Public Affairs was originally established by IUGS as a working group in 2001 based on the results of a survey conducted at IUGS's request by the American Geological Institute to better understand the policy issues that the union's members believed to be of greatest importance and to determine what activities were being undertaken to address those issues. Although the survey showed a wide range of levels of activity, it was clear that there were opportunities for collaboration and strong interest among the members in doing so. An article about the working group, including a summary of the survey and a number of success stories, appeared in a previous issue of Episodes (Applegate, 2002). The current Task Group is chaired by the author and has representatives from 18 countries and organizations.

\section{Current Activities}

In the current year, the Task Group responded to two separate pleas for international support by national geological surveys that were threatened with elimination. The goal of this Task Group is to share information on geoscience-related public policy activities that are taking place around the globe, focusing on the common challenges faced by geoscientists in many different countries. The threat of elimination of geological surveys is certainly a common challenge as governments often fail to recognize the contributions made by their own geoscientists in assessing resources, identifying natural hazards, and monitoring environmental indicators.

In January, the Colombian government sought to close INGEOMINAS, that nation's geological survey, which had a long and distinguished history dating back to 1916. The Task Group representatives were contacted by electronic mail and urged to communicate support to political leaders in Colombia. A number of Task Group representatives responded to the call. IUGS's own leadership also organized a response to this problem as did leaders of many IUGS affiliated societies.
In July, it became apparent that threats to national geological surveys are a recurrent theme in geoscience policy. The threatened entity in this case was the Instituto Geologico e Mineiro (IGM) or Geological and Mining Institute of Portugal, which was established over a century and a half ago. Supporters of the IGM developed a petition that was to be sent to the Portugese President, Prime Minister and Council of Ministers. Task Group representatives were encouraged to sign the petition and spread the word about it as well.

Because responses to the initial survey that led to the Task Group's formation came primarily from national representatives, a second survey has been distributed to the affiliated organizations of IUGS in the hope of better characterizing the public affairs activities of geoscientific societies around the globe. The results from that survey will be posted on the Task Group web site.

The Task Group will meet in person for the first time at the 32nd International Geological Congress, which is taking place on August 20-28, 2004. The Congress's Organizing Committee has graciously offered to host such meetings for IUGS Task Groups. A number of Task Group representatives are expected to attend, and additional participation is welcomed.

\section{Contacts}

For more information about the Task Group, including a roster and several of the documents cited above, please visit http://www.agiweb.org/gap/iugs. If your organization is interested in assigning a representative to the Task Group, please contact the author. We are eager to have the broadest participation possible and welcome any suggestions on future activities that the Task Group could undertake that would be valuable to IUGS and the global geoscience community. If you are aware of geoscience policy developments in your country or elsewhere that could benefit from action by the international community, please contact the author for distribution to the Task Group.

\author{
References \\ Episodes 25/2, 79-83. \\ David Applegate \\ American Geological Institute \\ 4220 King Street \\ Alexandria VA 22302 \\ USA \\ E-mail: applegate@agiweb.org
}

Applegate D 2002. New IUGS Working Group addresses public affairs. 